\title{
Earthquake geology and hazards in Taiwan
}

A violent reminder of active mountain building in Taiwan arrived early on September 21st, 1999 as a Mw 7.6 earthquake first shook the small town of Chi-Chi and subsequently propagated along the active thrust belt, causing over 2300 fatalities and great economic loss. Immediately recognized as the most accurately recorded large thrust earthquake since the advent of modern seismology, the event galvanized efforts by Taiwanese and other geoscientists to define how recent strain in the orogen is being shed during large earthquakes. These included accelerated efforts by researchers at Taiwanese universities and government agencies in addition to new collaborative efforts with other Western and Asian research groups who leaped at the opportunity to work in such an exciting setting. High strain rates that result in large earthquakes, well defined Quaternary stratigraphy and geochronology, a comprehensive set of trench excavations, access to subsurface data and digital surface topography were all used in comprehensive efforts to define how the Chi-Chi event unfolded and how it was related to past events. While this work was focused on defining the Late Holocene history of strain release on the thrust that ruptured in 1999, subsequent work then spread to an array of other rapidly slipping faults in the orogen formed in a number of different seismotectonic settings.

The Taiwanese orogen hosts a remarkable array of active structures, formed in response to subduction across two separate plate boundaries. The bulk of the Island records growth of a west-vergent, thrust belt formed by accretion of the Luzon Arc onto the Chinese continental margin. Extending northward from an accretionary wedge to the south, the western thrust belt of Taiwan is manifested by a line of frontal fault-related folds formed above blind thrusts and a series of progressively exhumed thrust sheets. Distinct segments of the western thrust belt are typically related to the architecture of the accreted passive margin. The backstop for the orogen is marked by the onshore portion of the Luzon arc, exposed in the Coastal Range along the eastern edge of Taiwan. Modern strain gradients as defined by the Taiwanese geodetic network suggest high rates of oblique convergence across this important boundary, which is partitioned into rapidly slipping strike slip and thrust faults in the Longitudinal Valley. Conversely, northern Taiwan is currently extending in a back-arc setting related to northward subduction of the Philippine Sea plate beneath mainland Asia. This region contains the densely populated Taipei Basin, where recent study of active normal faults has begun to define the paleoseismic history of the area and the potential for future seismic hazard. As the architecture of active strain became better defined throughout Taiwan in the wake of the 1999 event, catalogs of paleoseismic events, fault slip rates and other key data for assessing seismic hazards were increasingly developed. Trench excavations, reaching into the past history of surface displacements shed light on surface thrust processes, new faults were recognized as being active and high resolution LIDAR was flown to characterize subtle surface strain.

We are pleased to present results of this research in earthquake geology and seismic hazards as a special issue of the Journal of Asian Earth Sciences. Developed from a topical session on Taiwanese earthquake geology and seismic hazards presented at a meeting of the American Geophysical Union, contributions to the volume draw from an array of settings around Taiwan. These include studies of the thin-skinned western thrust belt, the active locus of collision and strike slip faulting along the volcanic arc accreted onto the eastern side of the Island, and the active extensional fault systems that bound the densely urbanized Taipei basin. The 13 papers that comprise this volume thus present efforts from a diverse set of active structures that are expressed at the surface as thrust, strike slip and normal fault ruptures and fault-related folds.

Papers in the volume begin with a regional analysis of fault segmentation in Taiwan by Sugiyama and its comparison to similar structures and basins in Japan. Papers by W. Chen, Y, Ota and J. Lee and colleagues focus on details of surface deformation associated with the 1999 earthquake and the paleoseismic evidence for past events and styles of surface strain. Variation in sedimentation rates along the length of the Chelungpu thrust lead to very different styles of strain produced at the surface during the 1999 
event, and papers in this volume illustrate the detailed relationships between synorogenic sedimentation and deformation at earthquake recurrence timescales. A contribution by Y. Chen and coauthors examines how strain is accommodated along the leading edge of the thrust belt, where large active folds form above blind thrusts. This study utilized a well-preserved flight of fluvial terraces and subsurface geology to argue for the complete accommodation of fault slip at shallow levels by surface folding.

Two other studies by C. Lin and C. Yang and their colleagues focus on the seismic sources in southwestern Taiwan, including the Chiuhsiungken Fault that marks the emergent mountain front and blind faults underneath the coastal plain. Strain in this region is marked by fault architecture formed in a narrow belt of thrusts located at the leading edge of the belt. Contributions defining the earthquake geology and seismic hazards of active normal faults in the densely urbanized Taipei Basin are presented by Huang et al., and Song et al. This region has been a focus of greater attention in the wake of the 1999 event due to the proximity of large normal faults in this region to the city of Taipei, and the fact that little was known about these structures prior to this work. In southern Taiwan, J.Hu and colleagues assessed the activity of active faults using a dense GPS network. Their results suggest the Kaopingshi and Chishan faults are aseismic and creeping in the western Pingtung plain, whereas the Chaochou fault, which bounds the western side of the basin is currently locked. This is an important constraint for the seismic hazards of a region that has undergone rapid recent urbanization and population growth.

An analysis of faulting in the transition between active shortening in the western thrust belt and extension in the northern part of the Island is presented by Chan et al. These authors use high resolution LIDAR data to identify and map subtle strain, important not only for the densely urbanized nature of the deformed region but for their digital "de-urbanization" of buildings and infrastructure to highlight fault and fold scarps. This is an exciting development for assessing seismic hazards in densely urbanized cit- ies and allows subtle folds and thrust scarps to be defined over a broad area in remarkable detail.

The last two papers by Shyu et al., and Kuochen et al., are aimed at eastern Taiwan, where very rapid shortening is partitioned with active strike slip faults along the volcanic arc, or backstop of the orogen. Some of the highest strain gradients on the Island have been defined by geodesy in this region, which marks the "backstop" for the entire orogen. Work presented in these papers combines accounts of historical events with fault structure and geomorphology of rapidly offset landforms to provide some of the first comprehensive surveys of active strain in the Longitudinal Valley.

In closing we thank the contributors, reviewers, and assistants for their efforts in reviewing and editing contributions and the editorial office of the Journal of Asian Earth Sciences for providing a venue for this work and assistance in producing this special issue. Reviewers who helped to edit papers in the volume include: T. Azuma, JP Avouac, K. Berryman, R. Bilham, Y.C. Chan, C.H. Chen, H.T. Chu, S. Dominguez, T. Fumal, S. Hardy, T. Ishiyama, P. Jansma, K. Johnson, H. Kelsey, K. Kelson, L. Kirstein, J.C. Lee, T.C. Liu, A. Meigs, A. Nelson, M. Oskin, Y. Ota, P. Pringle, C.M. Rubin, K. Ridgway, S. Roecker, I. Stewart, Y. Sugiyama, S. Thompson, H. Tsutsumi, R. Walker, R. Welden.

Guest editors Yue-Gau Chen *

Department of Geosciences, National Taiwan University, Taipei, Taiwan E-mail address: ygchen@ntu.edu.tw

Karl Mueller

Department of Geology, University of Colorado, Boulder, CO, USA

Ching-Hua Lo

Department of Geosciences, National Taiwan University, Taipei, Taiwan

Received 25 February 2004; received in revised form 18 February 2005; accepted 27 July 2006 